\title{
STATE OF MINING EDUCATION IN AFRICA: A CASE OF ZAMBIA
}

Webby Banda ${ }^{1}$ and Bunda Besa ${ }^{2}$

1,2 The University of Zambia, School of Mines, P.O. Box 32379, Lusaka Zambia

\section{Email: webby.banda@unza.zm and bbesa@unza.zm}

\section{Abstract}

The mineral industry needs a steady supply of skilled professionals entering the workforce, it must be recognized that as mineral development becomes more complex and technical the training of mineral industry professionals should be adjusted to reflect this. The mineral industry has undergone several changes in terms of technological advances, it is further envisioned that the future mine will rely on a highly skilled skeleton labour force with the ability to perform several tasks through automated and remotecontrolled operations and monitoring. This paper assesses Zambia's mining education to uncover whether the current state of mining education curricula is in a position to address the need of the future mining industry. This assessment was done based on four key areas of the future mine. These key areas have been identified as operating practices and technology, talent and leadership, partnership with key stakeholders, and governance. A comparative analysis with three mining Universities in the Southern African Development Community (SADC) region was undertaken. From the assessment, mining education in Zambia's two largest mining Universities, namely, the University of Zambia (UNZA) and Copperbelt University (CBU) needs to be refined to fully address the future needs of the mining industry.

Keywords: Mining industry, Skilled professionals, Future mine, Skills shortage, Technological advancements.

\section{Introduction}

Africa is richly endowed with a vast amount of mineral resources. As a continent, it is the world's largest world producer of important minerals of both domestic and international importance (Kaba, 2018). Mining is the main economic stay in most African economies contributing substantially to macroeconomic development. In many African countries, it contributes significantly to Gross Domestic Product (GDP), tax revenue generation, 
employment, Foreign Direct Investment (FDI), and export earnings (Banda, 2016a; Banda 2016b; and Besa et al., 2019). The industry also helps in improving the livelihood of the citizens through Corporate Social Responsibility (CSR) programmes undertaken by mining companies. These programmes dispense several amenities that translate into maximum social-economic benefits for the local communities that exist in proximity of mining operations. A skilled labour force is paramount in ensuring that Africa benefits from its natural resources. In doing so, it needs to narrow the current and projected future skills gap by investing in mining through building research centers and modernizing laboratories with up-to-date equipment and software. The wind for automation in mining cannot be redirected or reversed (Kaba, 2018). Mining companies also need to play their part by investing in their young engineering employees and recruiting talented students through partnerships with universities. This can be achieved by sponsoring the young engineering labour force to obtain higher degrees and educating the technical labour force about modern technology through organized short courses, seminars, conferences, and workshops. On the side of the students, there must be willingness and readiness to learn beyond the lecture theatre. Students must take a keen interest in acquiring knowledge that will make them employable in the long term. For instance, mining engineering students need to equip themselves with skills in programming, data science, simulation, and optimization. This itself will prop up their problem-solving, communication, and critical thinking abilities.

A rapid increase in technology in today's mining industry is demanding well-qualified mineral scientists to undertake strategic roles and leadership. To achieve this, universities offering mining education must channel their energy in producing well-qualified graduates that meet industry needs. In attaining this, there is a need to harness and establish a symbiotic relationship among government, tertiary institutions, and mining companies. Tertiary institutions offering mining education are always in a pressing need to obtain funding from mining companies and the government to support their academic activities. On the other hand, the mining industry is in a dire need of qualified mining personnel to increase the efficiency of its operations. Similarly, governments require efficient productive mines and highly qualified personnel to operate their offices. Close collaboration and cooperation among these entities is the only way to achieve maximum 
benefit for all. The triple helix model should be strengthened to make sure there is a strong link between the university, government, and industry. University-IndustryGovernment partnership should aim at achieving mutual benefit rather than being parasitical where only one or two parties benefit. Universities should be at the forefront of solving local industry problems. Governments on the other hand should formulate policies that support universities in research and public service. The mining industry should take up further roles in mentorship, advisory membership board, capacity in terms of providing guest lecturers, feedback via support in curriculum development, and support in terms of providing equipment. Paramount among these is a well-formulated advisory board that is influential in all aspects of mining education curriculum development.

For Africa to achieve economic progression and growth, It needs to utilize its mineral resources efficiently. To achieve this, there is a need for African governments to invest in mining education. There is a need to educate employable African citizens in readiness for the mine of the future which shall mainly be digital. Notwithstanding, this paper is focused on assessing the current state of mining education in Zambia. It discusses the preparedness of mining universities in Zambia to address the skills required for the future mine.

\section{An overview of mining education in Zambia}

Only two Universities in Zambia offer training in Mining Education. These are the University of Zambia (UNZA) and Copperbelt University (CBU). The former and the latter are Zambia's two largest Universities. UNZA through its School of Mines offers three mineral sciences degrees, namely Mining Engineering (BEng), Metallurgy and Mineral Processing (BEng), and Geology (BSc). Similarly, CBU through the School of Mines and Mineral Sciences offers four mineral sciences degrees, namely, Geology and Exploration (BSc). Mining Engineering (BEng), Metallurgical Engineering (BEng), and Minerals Engineering (BEng). The two Mining Schools play an important role in the national life of Zambia in training quality geologists, mining engineers, and metallurgists, who are needed by the current and future mining industry. To maintain relevance, the schools' have close contact with the mining industry. 


\subsection{Curriculum review and stakeholder support}

The school advisory boards in both Universities (CBU and UNZA) have made an immense stride in including members from the mining industry in curriculum review. The objective of this is to fine-tune the curriculum to deliver mineral scientists who can meet the pressing and dynamic needs of the mining industry. The curriculum review process in both Universities is traditionally school-driven but must be approved by the University Senate before implementation. Curriculum review is an important aspect that dictates the quality of graduates. It underpins the competitiveness of the university in the local and global markets. A good curriculum in mining education should:

(i) Define specific learning outcomes that students should meet;

(ii) Focus more on entrepreneurship skills than on employability;

(iii) Strike a balance between theory and practice;

(iv) Be overseen by a good quality assurance unit to ensure monitoring and evaluation of its effectiveness;

(v) Demonstrate the local significance and not developed for monolithic industry;

(vi) Be anchored on strong synergies of the Triple Helix Model (governmentuniversity-industry);

(vii) Be reviewed every after 5 years with flexible minor reviews done annually; and

(viii) Be benchmarked against best practices.

In light of the above, curriculum review is at its best when universities have wellestablished quality assurance units. A good quality assurance system should include monitoring and evaluation in the curriculum review process. The Higher Education Authority (HEA) and Zambia Qualification Authority (ZQA) have the core mandate to provide quality and standards in tertiary education at the country level. Furthermore, quality could be enhanced by accreditation to international boards such as Washington Accords (Musonda et al., 2019). 


\section{Principles of the future mine}

Mining technology over time has evolved from using handheld tools to the use of large high-tech equipment. There has been a refocus of the production away from labour to that anchored on mechanization. The application of autonomous mining systems is a rapidly growing development in mechanization. Autonomous mining systems can drive mining efficiency sustainably and cost-effectively. According to Kaba (2018), autonomous mining systems consist of the use of machines, robots, and communication systems to conduct mining operations with minimal human involvement in the process. The use of this system requires a few highly skilled employees. The autonomous mining system can be viewed as an integral component of the future mine. Yomeogo and Suarez (2013) envisage the future mine to be fully automated with smart technology, analytics, and machines that can interact with the rock and surrounding environment. This means that real data of the mining process shall be conveyed via a sophisticated wireless communication system into control rooms where important management decisions regarding safety and production can be made (Oshokoya and Tetteh, 2017). Although managing uncertainty is one of the critical factors of mining, the future mine will be sustainable and deliver value to its shareholders (Holland, 2017). According to Holland (2017), the four key areas for the future mine are operating practices and technologies; leadership and talent; partnerships with key stakeholders, and governance (see Figure 1). The mine of the future will demand competent and technical savvy mineral scientists that will be able to handle complex problems through the application of rigorous and robust solutions across all four areas highlighted in Figure 1.

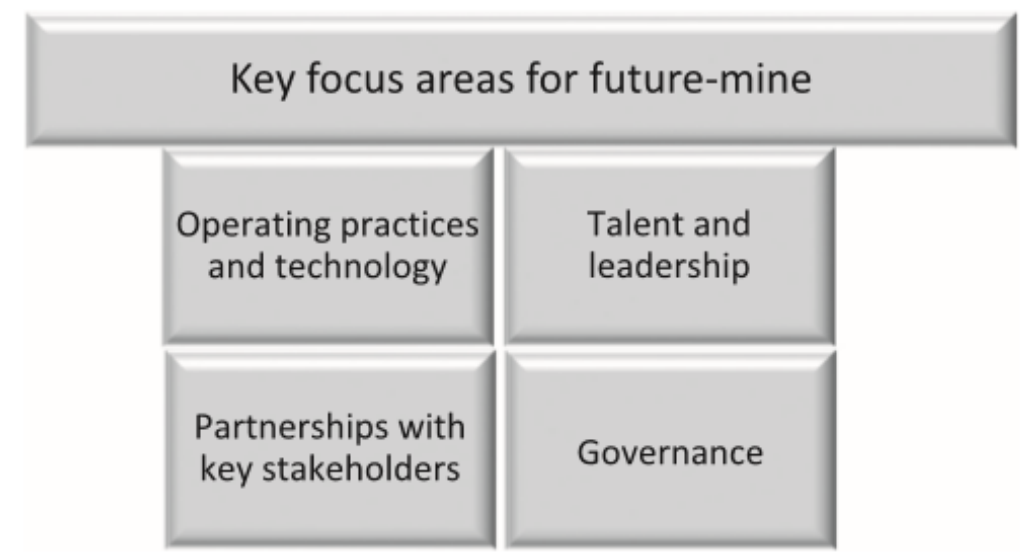

Figure 1 Focus areas for the future mine (Holland, 2018) 
As mining becomes increasingly automated the skills gap is widening. Therefore, there is a need to address this yawning gap through investment in tertiary education. Musingwini (2012) calls for the continuous training of mining skills to avert further skills shortage. Mills (2012) attributes skills shortage in the mining industry to increased demands in the resource industry and an aging workforce. Yamoego and Suarez (2013) posit that it is necessary to attract and retain the required young talent and equip them with skills that will enable them to operate the future mine. The mining industry needs to be forward-thinking and progressive to achieve this. Attracting the next generation of tech-savvy and environmentally aware employees will require rigorous marketing of mining programmes. This marketing will need to start from the classroom and will require convincing young professionals who do not have an affinity for mining education. One fact that must be appreciated is that the future mine will require few employees with high skills in various aspects of automation, database management systems, data science and technology, and social and environmental management (Yamoego and Suarez, 2013). The future mine will involve several integrated components. Gipps et al. (2011) identified some of the components of the future mine and these include a database model that drives knowledge; a control and evaluation system; sensors; communication systems; automated and remote-control plant and mobile equipment; operation interfaces; exploration, mining, processing, and transportation systems. These components are further explicated in Table 1. 
Table 1 Components of the future mine (Adapted from Yamoego and Suarez (2013) and Gipps et al. (2011))

\begin{tabular}{|l|l|}
\hline Future mine component & Key functions \\
\hline Knowledge-driven database & $\begin{array}{l}\text { Knowledge-driven database that gives information on } \\
\text { all activities of the mining operation. These include } \\
\text { geophysical, geochemical, geological, geotechnical, } \\
\text { environmental data, health, and safety data of miners, } \\
\text { health and status of mining equipment, metallurgical } \\
\text { data, etc. Several models of this nature include the } \\
\text { common mine model by Fraser and Hodgkinson } \\
\text { 2009) and the Wits Digital mine research database } \\
\text { model by Wits Mining Institute (Cawood, 2017). }\end{array}$ \\
\hline $\begin{array}{l}\text { Control and evaluation } \\
\text { system }\end{array}$ & $\begin{array}{l}\text { A system that monitors safety and risk in operations, } \\
\text { and automatically updates mine plans (Haustein et } \\
\text { al., 2008). The entire system is expected to ensure } \\
\text { safe and efficient mining and mineral processing. }\end{array}$ \\
\hline Sensors & $\begin{array}{l}\text { A sensor that provides real-time data on the mine and } \\
\text { processing environment as well as product quality } \\
\text { and quantity. These include gas and dust emissions, } \\
\text { tailings and water levels, etc. }\end{array}$ \\
\hline Communication systems & $\begin{array}{l}\text { Data transfer from the mine and processing } \\
\text { environment to a control room system. }\end{array}$ \\
\hline $\begin{array}{l}\text { Automated and remote- } \\
\text { control plant and mobile } \\
\text { equipment }\end{array}$ & $\begin{array}{l}\text { The equipment must be accessible to the common } \\
\text { mine model control room system and be remotely } \\
\text { operated. Such equipment should have onboard } \\
\text { intelligence automation systems that enable it to take } \\
\text { measurements of specific data from its environment. }\end{array}$ \\
\hline $\begin{array}{l}\text { Opxploration, mining, } \\
\text { processing, and } \\
\text { transportations systems }\end{array}$ & $\begin{array}{l}\text { This interface is meant to allow users to interact with } \\
\text { various systems in an efficient manner leading to } \\
\text { optimal performance of the mine and mineral } \\
\text { processing operations. This will enable operators to } \\
\text { have real-time user information regarding situations } \\
\text { on operational parameters and will prompt what future } \\
\text { actions may be required. }\end{array}$ \\
$\begin{array}{l}\text { Newly designed remotely operated, and automated } \\
\text { equipment }\end{array}$ \\
\hline Operation
\end{tabular}

\section{Assessment of the current status of Mining Education in Zambia}

An assessment was undertaken to determine the readiness of the current Zambian mining education system to equip students with the necessary skills required by the Mine of the future. In doing so, Zambia's two largest Universities offering mining programmes through their Mining Schools had to be originally considered. These are UNZA (School 
of Mines) and CBU (School of Mines and Mineral Sciences). The investigation of current mining education in Zambia was done by comparing the current state of the curricula against the main skills needed by the miner of the future. These skills are operating practices and technology; talent and leadership; partnerships with key stakeholders; and governance. It should be noted that this comparison was done purely in terms of what is stated as being contained in the curriculum of each Mining School and not in terms of the quality of delivery of those contents.

\subsection{Geology}

Table 2 shows the assessment of Geology education under Zambia's two largest Universities against the key four areas of the future mine. The number of Geology courses that each University offers are shown in Table 2. From the table, it appears that more weight under the two Universities is placed on operating practices and technology and less weight on the remaining key focus areas. CBU (School of Mines and Mineral Sciences) seems to do better than UNZA (School of Mines) under talent and leadership as well as partnerships.

Table 2 Zambian Mining Education Assessment - Geology

\begin{tabular}{|l|c|c|}
\hline \multirow{2}{*}{ Key areas } & \multicolumn{2}{|c|}{ Number of courses } \\
\cline { 2 - 3 } & $\begin{array}{c}\text { UNZA School of } \\
\text { Mines }\end{array}$ & $\begin{array}{c}\text { CBU School of Mines } \\
\text { and Mineral Sciences }\end{array}$ \\
\cline { 2 - 3 } & Geology (BSc) & $\begin{array}{c}\text { Mining and } \\
\text { Exploration Geology } \\
\text { (BSc) }\end{array}$ \\
\hline Operating practices and technology & 31 & 32 \\
\hline Talent and leadership & 0 & 1 \\
\hline Partnerships with key stakeholders & 1 & 2 \\
\hline Governance & 0 & 0 \\
\hline
\end{tabular}

\subsection{Mining Engineering}

Table 3 shows the assessment of Mining Engineering education under Zambia's two largest Universities against the key four areas of the future mine. The number of Mining Engineering courses that each University offers are shown in Table 3. From Table 3, under both Universities, more weight is placed on operating practices and technology. Less weight is placed on talent and leadership plus partnerships. Additionally, no courses 
deal with governance issues. However, it is worth noting that $\mathrm{CBU}$ (School of Mines and Mineral Sciences) and UNZA (School of Mines) are closely matched under the four areas.

Table 3 Zambian Mining Education Assessment - Mining Engineering

\begin{tabular}{|c|c|c|c|}
\hline \multirow{3}{*}{ Key areas } & \multicolumn{3}{|c|}{ Number of courses } \\
\hline & \multirow{2}{*}{$\begin{array}{l}\text { UNZA School of Mines } \\
\text { Mining Engineering } \\
\text { (BEng) }\end{array}$} & \multicolumn{2}{|c|}{$\begin{array}{c}\text { CBU School of Mines and } \\
\text { Mineral Sciences }\end{array}$} \\
\hline & & $\begin{array}{l}\text { Mine Planning } \\
\text { and Design } \\
\text { (BEng) }\end{array}$ & $\begin{array}{c}\text { Rock } \\
\text { Mechanics } \\
\text { (BEng) }\end{array}$ \\
\hline $\begin{array}{l}\text { Operating practices and } \\
\text { technology }\end{array}$ & 35 & 30 & 31 \\
\hline Talent and leadership & 1 & 1 & 1 \\
\hline $\begin{array}{l}\text { Partnerships with key } \\
\text { stakeholders }\end{array}$ & 3 & 4 & 3 \\
\hline Governance & 0 & 0 & 0 \\
\hline
\end{tabular}

\subsection{Metallurgical Engineering}

Table 4 shows the assessment of Metallurgical Engineering education under Zambia's two largest Universities against the key four areas of the future mine. The number of Metallurgical Engineering courses that each University offers are shown in Table 4. From Table 4. Under both Universities, more weight is placed on operating practices and technology. Less weight is placed on talent and leadership plus partnership and nothing on governance. CBU (School of Mines and Mineral Sciences) and UNZA (School of Mines) are closely matched under talent and leadership plus partnerships. However, UNZA seems to do better than CBU in the area of operating practices and technology. 
Table 4 Zambians Mining Education Assessment - Metallurgical Engineering

\begin{tabular}{|l|c|c|c|}
\hline \multirow{5}{*}{ Key areas } & \multicolumn{3}{|c|}{ Number of courses } \\
\cline { 2 - 4 } & $\begin{array}{c}\text { UNZA } \\
\text { School of } \\
\text { Mines }\end{array}$ & $\begin{array}{c}\text { CBU School of Mines and Mineral } \\
\text { Sciences }\end{array}$ \\
\cline { 2 - 4 } & $\begin{array}{c}\text { Metallurgy } \\
\text { and } \\
\text { Mineral } \\
\text { Processing } \\
\text { (BEng) }\end{array}$ & $\begin{array}{c}\text { Metallurgical } \\
\text { Engineering } \\
\text { (BEng) }\end{array}$ & $\begin{array}{c}\text { Mineral Engineering } \\
\text { (BEng) }\end{array}$ \\
\hline Operating practices and technology & 34 & 26 & 28 \\
\hline Talent and leadership & 0 & 1 & 1 \\
\hline Partnerships with key stakeholders & 3 & 2 & 3 \\
\hline Governance & 0 & 0 & 0 \\
\hline
\end{tabular}

\section{Comparative analysis of mining education in the SADC region}

A comparative analysis was undertaken to compare the current status of mining education in Zambia with three purposively sampled Universities offering mining education in the Southern African Development Corporation (SADC) region, namely, the University of Witwatersrand, the University of Namibia (UNAM), and the University of Dar es Salaam. Figures 2, 3, and 4 show a summary in percentage terms of the current number of courses that each University offers through its Mining School under the four key points of the future mine. From Figures 2, 3, and 4, It can be deduced that all five Universities under Geology, Mining Engineering, and Metallurgical Engineering place more weight on operating practices and technology. Some weight is placed on partnerships. Very little weight is placed on talent and leadership and little or no weight on governance. The mining education curricula of CBU, UNZA, UNAM, University of Dar es Salaam, and the University of Witwatersrand are closely matched in addressing the requirements of the future mine. It is observed that under CBU, UNZA, UNAM, and the University of Witwatersrand no weight is placed on governance except for the University of Dar es Salaam which offers a couple of governance courses under Mining and Metallurgical Engineering. In equipping the future miner with governance skills, the five Universities need to increase the number of governance courses in their curricula. 


\section{Geology Education}

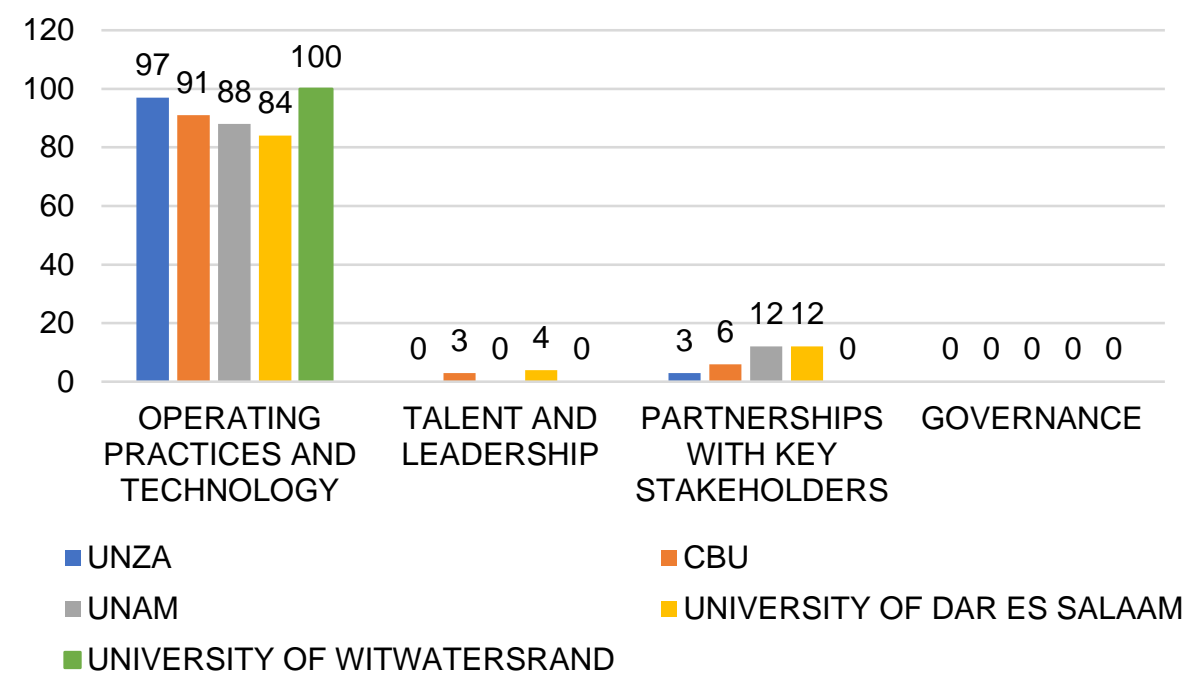

Figure 2 Comparative analysis of Geology Education

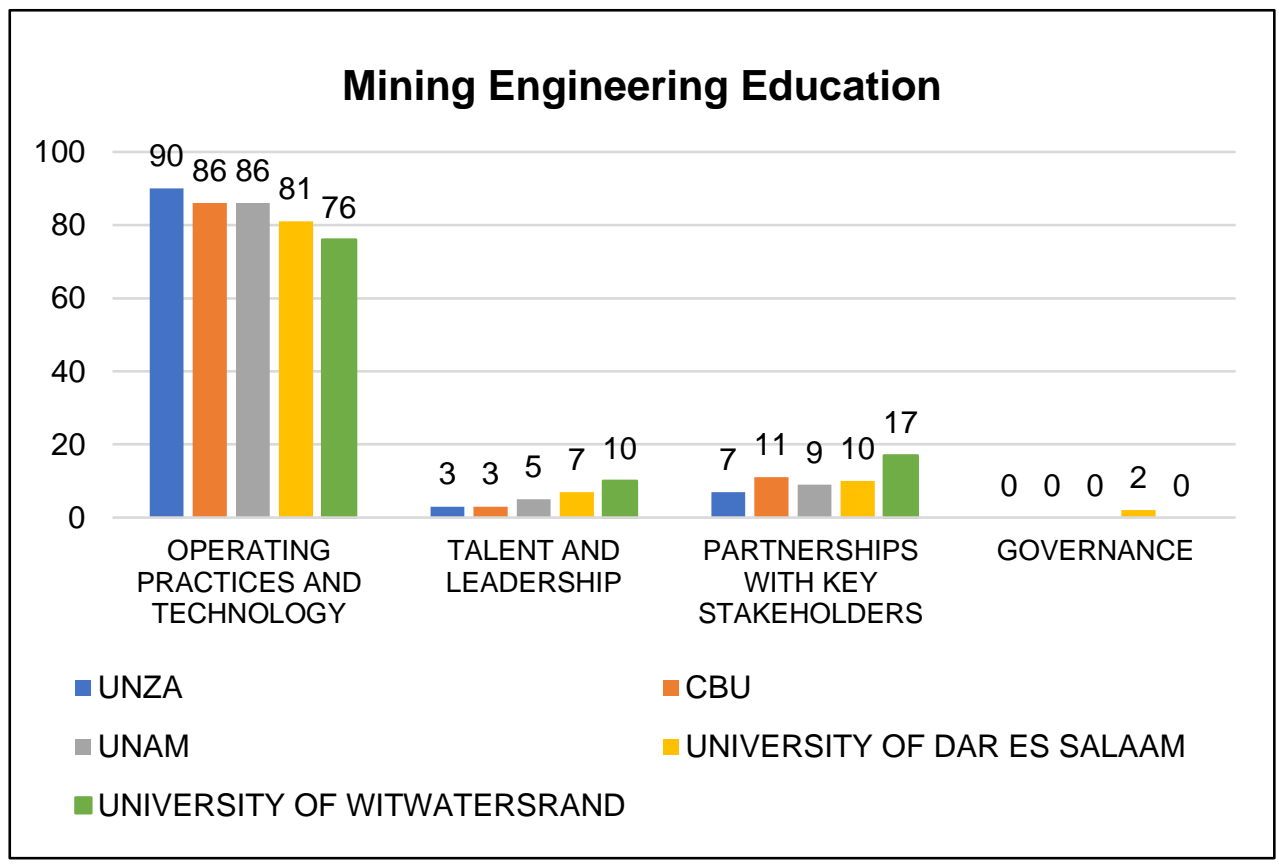

Figure 3 Comparative analysis of Mining Engineering Education 


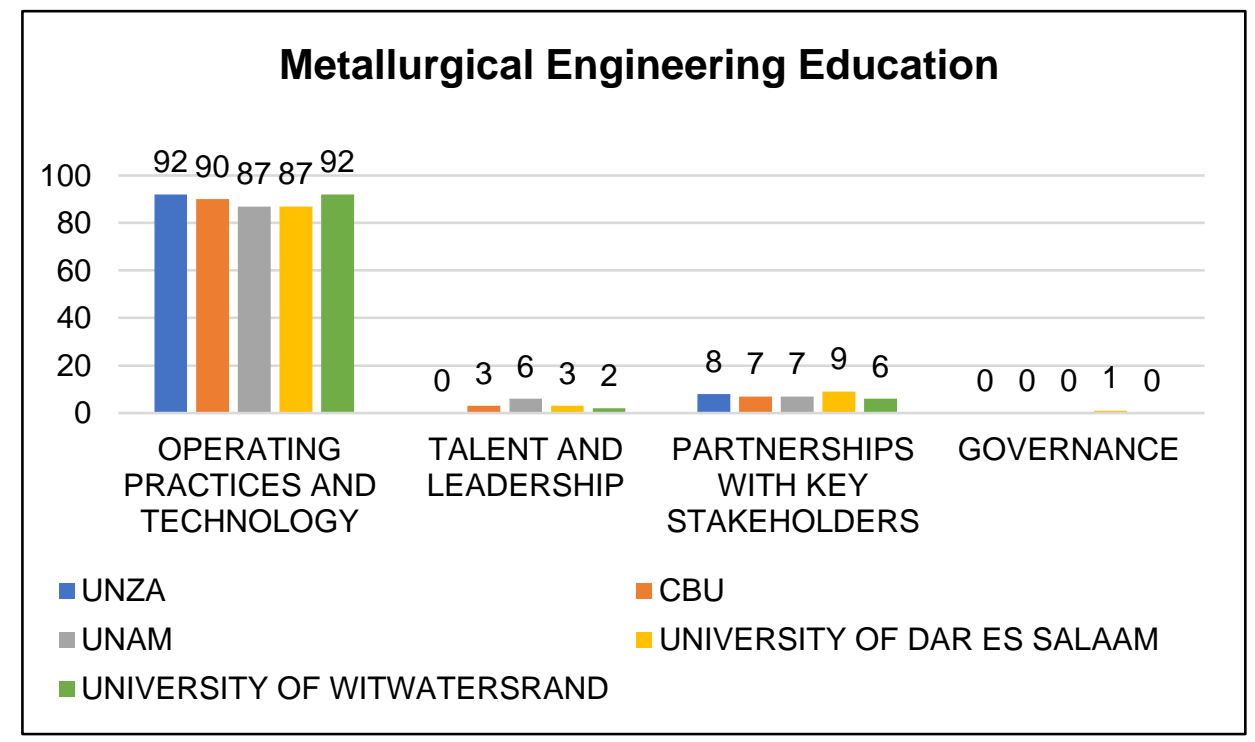

Figure 4 Comparative analysis of Metallurgical Engineering Education

\section{Conclusion}

In many more years to come, mining will undergo an immense transition from being conventional to being mechanized. At the heart of this mechanization, autonomous mining systems shall be fully embraced to increase the productivity, safety, and profit levels of mining ventures. A lingering question is whether mining institutions in Africa have curricula that will meet the demands of the future mining industry. In meeting the skill sets of the future mine. African mining institutions will need to establish state-of-theart research centers, experimental mine sites, and the incorporation of courses in their curricula that meet the demands of the future mine. In achieving this, triple helix synergies of government-industry-mining companies need to be strengthened. In this paper, Zambia's mining education was assessed with the main objective of determining whether it is capable of meeting the needs of the future mining industry based on four key areas discussed under Section 4. From the assessment, it was deduced that more weight is placed on operating practices and technology. Conversely, little weight is placed on partnerships with key stakeholders and talent and leadership and no weight on Governance. It is recommended that mining institutions in Zambia need to introduce more courses in the other three areas. This should be pursued to fully address the needs of the future mine. 


\section{References}

Banda, W., \& Besa, B. (2016a). Economic appraisal of Zambia's mineral taxation regimes. American Scientific Research Journal for Engineering, Technology, and Sciences, 18(1), 279-296.

Banda, W. (2016b). Evaluation of Zambia's mineral taxation regimes: a case study of Lumwana Mine. Master's Thesis, University of Zambia. https://pdfs.semanticscholar.org/6b53/4d9bd6a5244238eb8311253e9ef84fa4b7fc.pdf.

Besa, B., Kabwe, J., Masinja, J., \& Banda, W. (2020). Socio-Economic Impact of Mine Closure and Development of Exit Strategy for Rural Mining Areas in Zambia: A Case Study of Kalumbila District. Topal E. (eds) Proceedings of the 28th International Symposium on Mine Planning and Equipment Selection - MPES 2019. Springer Series in Geomechanics and Geoengineering. Springer, Charm. doi:https://doi.org/10.1007/978-3030-33954-8_48

Cawood, F. (2017). From the Directors Desk (online). Retrieved July 5, 2021, from 〈https://www.wits.ac.za/media/witsuniversity/research/wmi/documents/WMI\%20newsletter\%20July\%202017.pdf

Fraser, S., \& Hodgkinson, J. H. (2009). The Integrated Intrepretation of geophysics for resource discovery and mine planning. Proceedings of the Fifth Annual Asia Mining Congress, (pp. 52-53).

Gipps, I., Cunningham, J., Fraser, S., \& Widzyk-capehart, E. (2011). New to the Future - a path toward the future mine. Second International Future Mining Conference. Sydney: NSW, 22-23 November.

Haustein, K., Widzyk-capehart, E., Beitz, A., \& Hainsworth, D. (2008). A real time risk management system for mine safety. Proceedings of the Queensland Mining Industry Health and Safety Conference. Townville, 17-20 August.

Holland, N. (2017). Overview of the future mine. Johannesburg, South Africa: Presentation made on the 120 annivesary celebration of the University of Witwatersrand.

Kaba, I. (2018). Top Ways to Close the Gap between Mining Education in Africa and the Future Needs of the Industry. Retrieved from http://mining.com/richard-mills-massive-talentgap-in-mining-industry/3330/(Accessed

Mills, R. (2012). Retrieved August 12, 2019, from Massive Talent Gap in the Mining Industry: http://mining.com/richard-mills-massive-talent-gap-in-mining-industry/3330

Musingwini, C., Cruise, J. A., \& Phillips, H. R. (2012). A Perspective On the Supply and Utilisation of Mining Graduates in the South African Context. Platinum: South African Institute of Mining and Metallurgy (SAIMM).

Musonda, E., Muya, M., Zulu, A., Mwiya, B. K., Sichilalu, S., \& Mpanga, S. (2019). Review of Engineering Education Curriculum: A University of Zambia Perspective. The Engineering Institution of Zambia (EIZ) 2019 symposium. Livingstone, Zambia, 26-27 April 2019.

Oshokoya, P. O., \& Tetteh, M. N. (2017). Mine of the Future: How is Africa Prepared from a Mineral and Mining Engineering Perspective? Resources Policy, 125-133. 
Yameogo, T., \& Suarez, J. (2013). Education is the stumbling block for the mines of the future. Retrieved November 18, 2019, from http://0-

www.onemine.org.innopac. wits.ac.za/document/document.cfm?Docid=214273 